\title{
LOCAL PERCEPTIONS, KNOWLEDGE SYSTEMS AND COMMUNICATION PROBLEMS AROUND THE CLIMATE CHANGE DISCOURSE - EXAMPLES FROM THE PERUVIAN ANDES
}

\author{
Anja Weber and Matthias Schmidt \\ With 1 figure and 2 photos \\ Received 25 April 2016 · Accepted 01 December 2016
}

\begin{abstract}
Summary: This article depicts the connections between the global climate change discourse and local perceptions in the Global South using the example of village communities of the Peruvian Andes. We argue that it is necessary to understand how the global climate change discourse is transmitted, processed and adapted under specific local and socio-cultural circumstances. Our argument is based on the assumption that not only physical climate change processes influence ecosystems, economies and societies, but the discourse alone impacts livelihoods and daily routines worldwide. In this context, we discuss how the international climate change discourse is embedded in local discourses, thus defines how humans interact with existing assumptions and behaviours. Further, the discourse acts within existing global structures and runs the risk of sustaining or even reinforcing inequalities, thus excluding those who are considered to be the most vulnerable. Therefore, local knowledge must be recognised and seen as an equal aspect of (inter)national knowledge communication, creating a new balance in an equal and integrating way. This implies the need to consider national or local discourses, existing power structures and prevailing worldviews in which perceptions of time, environment, and climate are embedded. Insights from a case study in the Peruvian Andes illustrate our argumentation.
\end{abstract}

Zusammenfassung: Der Aufsatz fokussiert die Verknüpfungen zwischen dem global wirkmächtigen Klimawandeldiskurs und dessen Wahrnehmung im Globalen Süden am Beispiel von Dorfgemeinschaften in den Peruanischen Anden. Wir heben die Notwendigkeit hervor, Verständnis darüber zu erlangen, wie der globale Klimawandeldiskurs vermittelt und unter spezifischen lokalen und soziokulturellen Bedingungen verarbeitet und aufgenommen wird. Unserer Argumentation liegt die Prämisse zugrunde, dass nicht nur physische Klimawandelprozesse Ökosysteme, Ökonomien und Gesellschaften beeinflussen, sondern dass allein der Diskurs das Alltagsleben und Livelihoods weltweit beeinflusst. In diesem Kontext analysieren wir, wie der internationale Klimawandeldiskurs in bestehende lokale Diskurse, Annahmen und Handlungsweisen eingebaut wird. Durch das Wirken des Diskurses innerhalb existierender globaler Strukturen besteht die Gefahr, Ungleichheiten zu perpetuieren oder gar zu verstärken, da gerade die verwundbarsten Gruppen ausgeschlossen sind. Aus diesem Grunde plädieren wir für eine stärkere Berücksichtigung lokalen Wissens, das im Rahmen der internationalen Wissenskommunikation gleichwertig zu betrachten und zu integrieren ist. Demnach müssen nationale und lokale Diskurse, bestehende Machtstrukturen und herrschende Weltanschauungen, in denen Wahrnehmungen von Zeit, Umwelt und Klima eingebettet sind, stärker beachtet werden. Erkenntnisse einer Fallstudie aus den Peruanischen Anden illustrieren unsere Argumentation.

Keywords: Climate change discourse, local perceptions, knowledge systems, qualitative research, Peruvian Andes

'What do you think is climate change?' 'Climate change is - after what they say in the radio and what scientists say - that the ozone layer breaks little by little.'

'And how does this work?'

'Because of the smoke [...]; every day we burn and therefore it is damaged, also by the factories and that we use the cars like toys and their smoke, this as well produces pollution'. Mariano, 56 years, Llusco, Peru (10/2013)

\section{Introduction}

The above interview sequence from a small community in the Peruvian Andes depicts how information about the internationally discussed anthropogenic induced climate change is globally prevalent and even reaches people in peripheral areas of the
Global South. As elsewhere, people are confronted with a variety of information which is then processed in very different ways. The quotation adumbrates the power of a global discourse, and in which way transmitted information is processed and modified by the recipients. However, more often than not these voices have been unheard and ignored, both in sci- 
entific studies and in politics. In order to design and adjust climate change related adaptation measures so that they are regionally and socially specific, recognition of local perceptions of a forceful and influencing discourse is required. We emphasise the need to understand how the global climate change discourse is transmitted and processed under specific local and socio-cultural circumstances. Our argument is based on the assumption that not only do climate change processes influence ecosystems, economies and societies all over the world, but that the discourse alone impacts livelihoods and daily routines worldwide.

Climate change matters (OFfen 2014), not only in science but also in political agendas and society since it is seen as one of the major problems of our time. The status reports from the Intergovernmental Panel on Climate Change (IPCC 2001, 2007, 2013) are intensively discussed worldwide and influence political agendas on all spatial levels. Consequently, current climate change related knowledge has become global knowledge, implying 'universal authority' (Hulme and Mahony 2010, 714). The climate change discourse is communicated through diverse channels and consequently interpreted, processed, and appropriated from various socio-cultural perspectives, then reflected in the adaptation modes and strategies of different actors as well as in their perceptions and specific societal views. Therefore, even 'knowledge that is claimed by its producers to have universal authority is received and interpreted very differently in different political and cultural settings' (Hulme and Mahony 2010, 714). Thus, an understanding of 'local' or situated (LONG MARTELLO and JASANOFF 2004, 15) perceptions of the climate change discourse might help to recognise the affects that a dominant discourse has on its audience and the reasons for acceptance, appropriation, or resistance.

The aim of this article is to depict the connection between the international climate change discourse with its prevailing power structures and local perceptions in the Global South. Insights from a case study in the Peruvian Andes illustrate our argumentation. We start with a brief historical outline of the climate change discourse development, which shows how climate change became a 'travelling idea' 'made 'local' by a multitude of actors in a diversity of sites all over the world' (Weisser et al. 2014, 112). We then outline the communication and translation of the discourse from global to local levels, and discuss the different knowledge systems and cultural misunderstandings with examples from the Peruvian Andes. The appropriation of the climate change discourse and its entanglement with other discourses and how this led to the reification of existing power structures is explicated. In the conclusion we summarise the findings and call for a stronger recognition of local knowledge, perceptions and appropriations.

\section{Climate change discourse development}

Following Foucault, discourse is a linguistic materiality that is institutionalised through a social way of speaking (JuNG 2006). Thus, discourse is produced by social practices together with a constitution of knowledge and meaning with built-in power and resistance effects (WeEDON 1987; Foucault 1988). This means that a discourse has the ability to create reality (KeLLER et al. 2006) and develop effects of power by connecting an institutionalised way of speaking with actions that are assumed to be drivers for social change. What is currently regarded as truth is the result of negotiation processes between different knowledge systems implying an execution of power. Climate policy does 'not simply happen as a reaction of policy makers to newly emerging problems [...]. Rather they are brought about because certain types of knowledge, perceptions, awareness, interests and values are negotiated and become powerful in public discourses' (CANNON and MüLlerMaHn 2010, 630). Accordingly, adaptation to climate change is not just a rational response to meteorological parameters; it is mainly influenced and promoted by discourses derived from this phenomenon (WEISSER et al. 2014).

How did, however, today's climate (change) knowledge become global knowledge? History shows that dealing with changing climatic conditions or natural extreme events are not new topics for societies. It is even assumed that several civilisations collapsed in conjunction with extreme climatic events, such as the Maya in Central America or the Moche along the Peruvian coast (BAwden 1996; Grube 2000). The connection between climate and humans has interested scientists for centuries (VON StOrch and STEhr 1997; Hastrup 2013). However, today's growing public perception and concern for a human induced climate change only evolved in the last century; first within science, later in politics and media (ETKIN and Ho 2007; WeINGART et al. 2008; Weart 2011).

The 'causal story' (VIEHÖVER 2011) of the climate change discourse, its emergence and transition to globally common knowledge, is mainly rooted in the entanglement of environmental and climate change discourses at the end of the 1960s (VIEHÖVER 2012). 
Climate change, in this sense, is considered to be the result of environmental misconduct and a threat to global society. Together with on-going urbanisation and industrialisation processes and arising globally shared problems, such as the ozone hole, shrinking habitats, biodiversity loss or melting glaciers, a common assumption arose; that local actions have global consequences (HANNigan 1995; WeART 2011). A politicisation of climate (change), strongly supported by science-based knowledge, took place at the end of the twentieth century and led to the formation of an international climate regime and introduced climate change as a 'global vocabulary' (Diemberger et al. 2012, 227). The publication of predictions, especially those from the IPCC Assessment Reports in 2001 and 2007 forecasting a significant global temperature rise, can be considered as moments that lead politicians to start paying greater attention to climate change. Simultaneously climate change adaptation and mitigation projects, a 'hectic activism' (WEINGART et al. 2008, 13) or projectitis, commenced. Even though dissenting voices still existed, the media and public more or less accepted the approaching crisis; global warming.

Certainly the formation of the international climate regime has been a major (political) achievement, resulting in climate change knowledge becoming common global knowledge with almost universal authority (Hulme and MaHONy 2010). Hence the communicability of (scientific) climate information has become a crucial resource of institutional legitimacy (VIEHÖVER 2011). Based on the assumption that localities are never isolated from regional, national or global actions, structures and developments and are thus part of the global (HASTRUp 2013), we argue that today's global climate change discourse reinforces power structures and existing inequalities, leaving certain actors and places in disadvantageous or weaker positions.

\section{Climatechangecommunication and knowledge systems}

Climate change became a global narrative and an influential discourse, even though its understanding and interpretation are far from being unambiguous rather instead part of political, social and cultural circumstances and processes. IsAKSEN and STOKKE (2014), for example, identify three different main climate discourses in India; 'the Third World, WinWin and Radical Green discourses' which are based on different constructions of identity, interests, policy orientations and climate change exposure. Arnall and Kothari (2015) use the Maldives as an example to distinguish elite and non-elite perceptions of climate change related to the awareness of urgency and crisis, while Lo (2016) identifies four distinctive public discourses in Hong Kong; 'Pure Environmentalism, Political Pragmatism, Popular Optimism, and Fair Rationalism.' An evaluation of the three discursive frameworks, adaptation, resilience and vulnerability, and how they address climate change is conducted by Popke et al. (2016) using the example of agricultural transformation in Jamaica. All studies show various interpretations of the climate change discourse and its exploitation for economic and political reasons.

Additionally, what climate change means for the individual and how it is perceived, processed and translated into action is strongly influenced by social and cultural contexts (CRATE 2011; OfFEn 2014). Agrawal $(2010,173)$ considers the adaptation to climate change as 'highly local' and pointedly names the role and importance of local communities and cultures. In this sense, by analysing lay understandings of climate change, Hanson-EASEY et al. (2015) argue that increased attention should be directed towards the perception of non-scientists and for improved risk communication. Humans rarely respond on a purely rational base, or because of their knowledge of environmental processes (BRACE and Geoghegan 2010; Voss 2010). Rather, their actions are always formed by the combination of their (cultural) worldview and social relations, influenced by power structures and economic factors (CAREY 2010). In addition to immediatly felt physical impacts of a changing climate, the international climate discourse already impacts livelihoods and daily routines. This is stated by Bose (2016) who emphasizes the strong impact of development projects related to climate change in Bangladesh, a country that is seen as extremely vulnerable to the effects of climate change. Such projects significantly influence local communities irrespective of physical climate change consequences.

Information on climate change is communicated via different channels - media, education systems or politics. Due to its close conjunction with national policies and the implementation of projects on the ground, development organisations have been important transmitters of climate change knowledge, to the extent that it even reaches remote rural areas in the Global South. Although environmental change and its associated risks have been discussed by development cooperations since the Earth Summit in 1992 
(GTZ 2008), a significant amount of time passed before developmental issues found their way into the climate change discourse, and vice versa (DIETz 2006; SCHIPper 2007; Román et al. 2012). Various reports (IPCC 2007; UNDP 2008; World BANK 2010, 2012) showed that the predicted risks and negative effects of climate change will especially hit regions and societies in the Global South. Indigenous or rural communities living in risk prone areas are notably classified as highly vulnerable, as they, assumably, have lower adaptive capacities and are more dependent on climate-sensitive resources (ADGER et al. 2007). The World Development Report (World BANK 2010) pointed out that the expected consequences of climate change impede sustainable development and aggravate efforts to reduce poverty. Since then, climate change mitigation and adaptation measures have been both progressively mainstreamed at various political levels and implemented via various programmes, aiming to strengthen the resilience and adaptive capacity of local communities. However, PASGaArd et al. (2015) point to the production imbalance of climate change knowledge which primarily takes place in the Global North and seldom in the more vulnerable regions of the Global South.

Different knowledge systems and communication practices between North and South, global and local, are critical aspects within international cooperation. In this context, local, traditional or indigenous knowledge is often seen as inferior when compared to academic knowledge (NADASDY 1999; Long Martello and Jasanoff 2004). However, many science-based projects failed because local factors or specific perceptions of the population were ignored (CANNON and MüLLER-MAHN 2010) or as consequence of poor communication and failing knowledge transfer (TARNOCZI 2011). RAYGORODETSKY (2011) and WiLLiAMs et al. (2012) argue that local knowledge is hardly recognised in the global discourse and highlight the need to integrate such knowledge in climate related programmes and policies. The fact that views from the Global North dominate the discourse on climate security is emphasized by BOAS (2014) who asks for a stronger incorporation of views from the Global South. And the World Disasters Report $(2015,26)$ states that a 'culture of emulating Western organizational paradigms is promoted at the expense of local discourse and values, creating social distance and ignoring locally understood ways of working.' The international community responded with two requirements: First, to collect and integrate local knowledge, and second, to include more key persons capable of communi- cating climate change knowledge so that those concerned are able to interpret the information and act accordingly. These two mutually influencing points need to be further discussed.

\section{a) (Non)integration of local knowledge}

Within the international climate change discourse there is a lack of locally specific information (ADGER et al. 2007; Crate 2011). Even today, collecting and communicating information remains a challenging task for scientists and practitioners, inhibiting a response that should simultaneously consider sociocultural aspects and problems in situ. While data and information feeding the climate change discourse are mainly based on scientific knowledge (GERLAK and SCHMEIER 2014), a shift towards the recognition of local knowledge to face climate change related challenges can be identified. Some institutions, like the World Bank, standardised the management of this resource by collecting and spreading local knowledge through newly created data-bases (LONG MARTELLO and JASANOFF 2004). The UN University's Traditional Knowledge Initiative (UNU-TKI), established in 2007, aims to make indigenous knowledge accessible and promote their integration in the IPCC Assessment Reports (RAYGORODETSKY 2011).

However, while the international community creates, reinforces and furthers works with a dualistic concept of 'traditional' versus 'scientific' knowledge, it has been widely criticised (EsCOBAR 1995; HASTRUP 2013; WATSON and HunTington 2014) for reifying the underlying global inequalities and power structures. The problem of integrating traditional knowledge into land and resource management is derived from an understanding that the integration of knowledge systems is a technical problem in which traditional knowledge is seen as 'vastly different, and largely incompatible with, that of science' (NADASDY 1999, 2). So, traditional knowledge is only considered to be an addational 'data' set.

\section{b) Communication of climate change knowledge}

In the communication of climate change knowledge, a 'paradoxical rediscovery' (LONG MARTELLO and JASANOFF 2004, 4) of the local in global processes can be witnessed within the international climate regime. A shift became distinguishable within the IPCC, who moved away from a solely global or nearly global scale analysis of climate change impacts and 
towards more regionalised or even localised studies. The IPCC started to focus on vulnerability and adaptation matters of societies and ecological systems, as seen at side-events during the COP17 in Durban in 2011 which clearly demonstrated an attempt to better address and incorporate people-centred, local and indigenous aspects: 'Thinking globally, acting locally', or 'Climate Change and Indigenous People'. During the $32^{\text {nd }}$ IPCC session in 2010, it was stated that indigenous or traditional knowledge may prove useful for understanding the potential of certain adaptation strategies that are cost-effective, participatory and sustainable' (RAYGORODETSKY 2011). And KRONIK and VERNER (2010) outlined how adaptation strategies and mitigation instruments may be strengthened by incorporating a mutual dialogue between different knowledge systems; on the one hand from enriching data availability and on the other by showing if developed strategies meet the socio-cultural contexts in situ. Thus, the increased recognition of local knowledge and more culturally appropriate technologies support the statement that local communities are not only seen as victims of ecological problems, but as part of the global solution (LONG MARTELLO and JASANOFF 2004).

However, within the climate change discourse it is important to consider two further biases when looking at the global-local nexus. It is highly problematic to consider traditional, indigenous or local knowledge as an opposite static pole, or 'closed epistimological system' (HASTRup 2013, 276) with hardly any diversity and interference with the 'outer' world and thus 'modern' knowledge. Hastrup argues, not just that the existence of 'the' local knowledge is 'untenable' $(2013,276)$ but so is speaking about 'the' modern knowledge. We argue, however, that this dualistic aspect should be noticed, not only to underline both characteristics, but because a 'dualistic comparison' (NADASDY 1999, 2) between traditional and scientific knowledge is employed by governmental and non-governmental actors in climate change projects.

The second bias, deriving from the use of a dichotomous description of 'local' versus 'global' and 'traditional/indigenous' versus 'modern', is the fact that local places are interlinked in national and global networks and that scientifically generated knowledge found in the IPCC reports is also 'localized' (HASTRUP 2013, 276) knowledge. But the question arises, how could one knowledge system get the upper hand over the other and what does this mean for the underlying sociocultural systems and power structures. Insights from a case study in the Peruvian Andes will be used to support our arguments.

\section{The global-local nexus and discourse en- tanglements in the Peruvian Andes}

\subsection{Study area and Methods}

Our argumentation is supported by empirical ethnographic research conducted in the districts Llusco, Quiñota and Santo Tomás of the province of Chumbivilcas, department of Cusco (Peru) (Fig. 1). The research area is located at altitudes between $2,500 \mathrm{~m}$ and $3,600 \mathrm{~m}$ in the Southern Peruvian Andes with semi-arid climatic conditions (Photo 1). It is characterised by rurality with a total population of around 35,000 people in the three districts, representing a population density of around 15 persons per $\mathrm{km}^{2}$ (INEI \& Unidad Formuladora Santo Tomás, n.d.). Participant observation and in total 36 semi-structured interviews were conducted, between November 2012 and February 2014 during three field campaigns, with representatatives of governmental, national and international non-governmental organisations in Lima, Cusco and Santo Tomás and with different local actors in the three districts in Chumbivilcas. ${ }^{1)}$ By considering the different organisations scales, we were able to retrace climate information movements and their respective interpretations. Additional data were collected while attending national climate conferences and local workshops (Photo 2) as well as from project studies and reports.

\subsection{Cultural misunderstandings and dominant knowledge}

The above mentioned different knowledge systems, communication difficulties and divergent understandings of climate change have, of course, implications for the acceptance, appropriation and rejection of the climate change discourse 'on the ground' and influence communication between international, national and local scales. This will be illustrated by an example from the Peruvian Andes, where climate is defined and embedded differently into daily routines and worldviews. Here, the traditional concepts of time, space, and environment are derived from holistic and circular concepts. This implies, on the one hand, that climate itself is not considered to be a detached phenomenon because environment and human activities are in a state of

\footnotetext{
1) Interviews were conducted in Spanish; the citations in this article have been translated into English by the authors.
} 


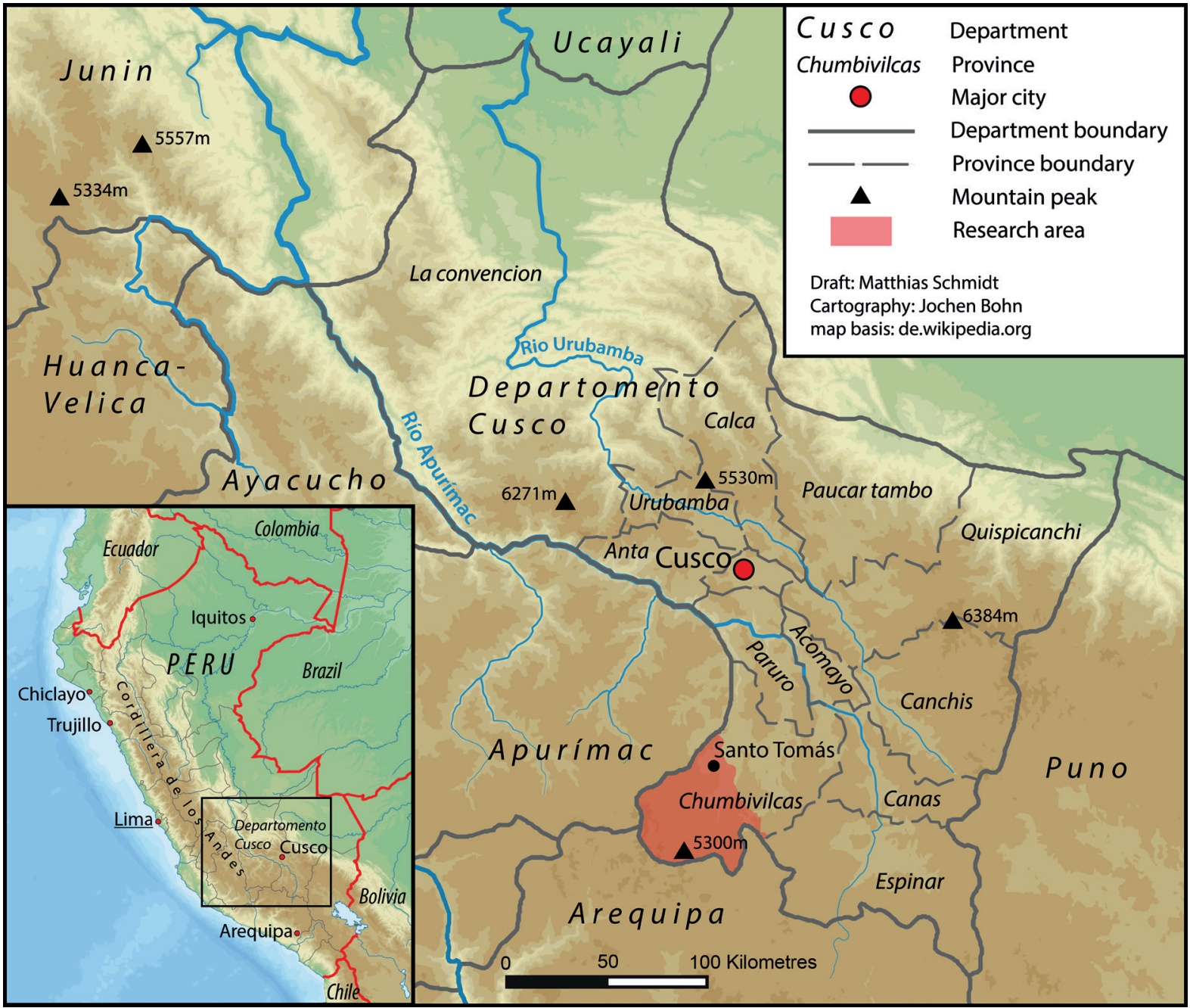

Fig. 1: Location of the study area

constant reciprocal action. Thus, a changing climate and its impacts, for example on agriculture, are important topics for the population but are always seen to be integrated into other environmental aspects. On the other hand, processessing a future-orientated concept like climate change predictions, one that originates from an occidental linear time-conception, contrasts with traditional circular temporal thinking which is dominated by living in the present, in a world where time itself is not lost but progresses, and where everything comes back in due time - such as the agricultural circle of the year (own investigations in Chumbivilcas).

In this context, during an interview with an organisation working on climate change adaptation in Chumbivilcas the project manager explained that the project intends to recover traditional knowledge and technologies. But viewing climate change only as a technical problem and local knowledge only as data can lead to implementation problems and thus frustration as the following citation by an organisation staff member illustrates: 'So what's missing? Your will [...]. Thus, you are aware but you are not acting.' Here, the fact that community members are 'not acting' is interpreted as missing will. But through the concepts of time briefly explained above, other reasons for the inaction are revealed, one being that they are just not accustomed to preparing themselves for future changes as the annual circle has taught them that everything will come back in its due time. This cultural misunderstanding was also mentioned by a young man who came back to Santo Tomás after studying in the city: 'There is not this circle anymore, the circle that they ran, and definitely no longer the vision of the future. Because you do not think that there can be changes later on.' 


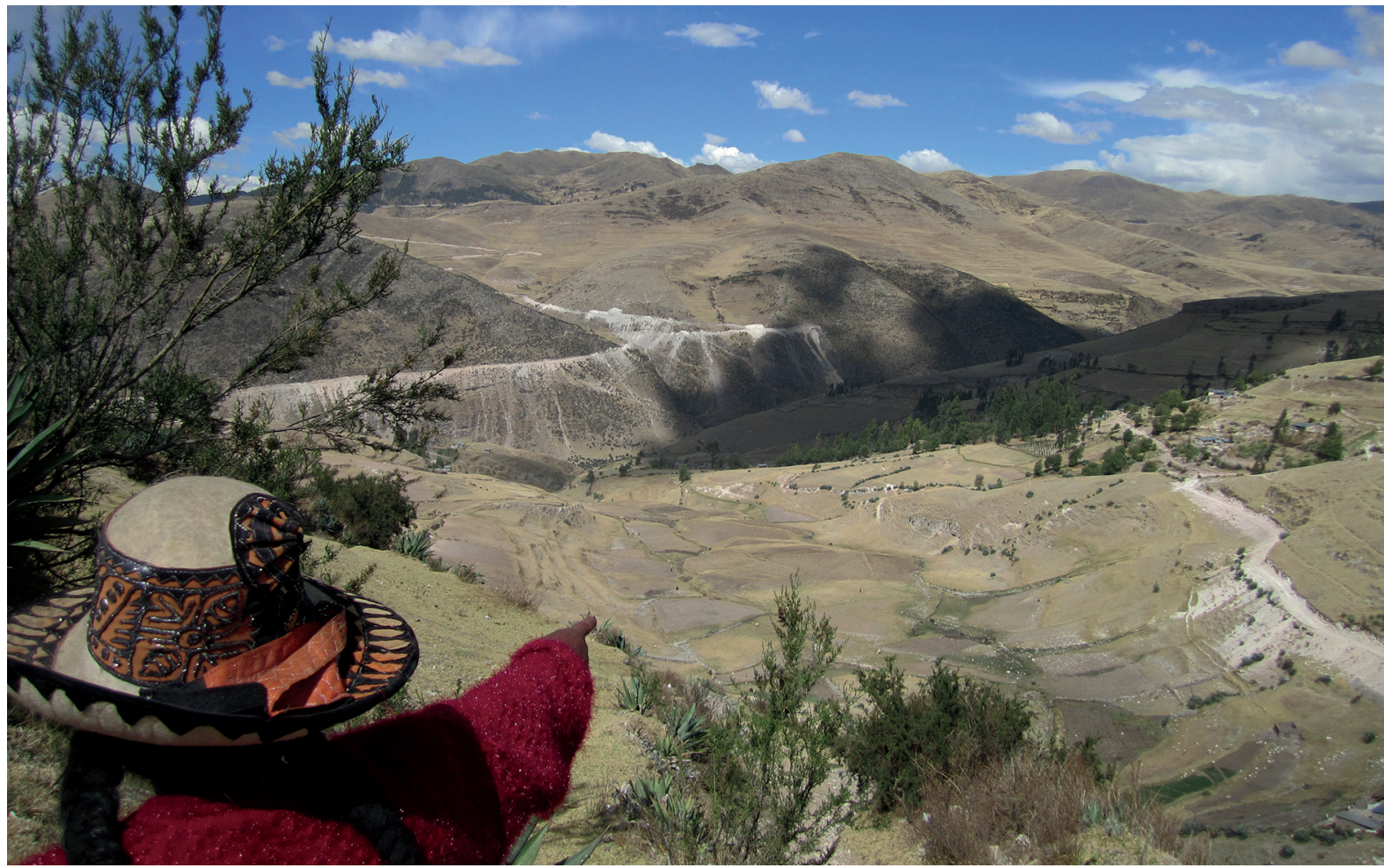

Photo 1: Semi-arid mountain landscape near Chacaraya, District Llusco, Department Cusco, Peru (Photo: A. WeBER, 21.09.2013)

A further question that arises is, what should be done in the end with the (recovered) local knowledge? Peru is undergoing major changes and developments, such as increased school attendance, extension of infrastructure like roads, electricity and telecommunication networks, and the arrival of different religious beliefs. This also leads to the abandonment of some traditional customs, an abandonment that results in more than just ceasing to conduct rituals, an example being traditional fumigating. This ritual is used between sowing and harvest to protect crops from a suddenly approching frost and has been abandoned by some who are 'turning their back' on old traditions. A higher occurance of frost-impacted crop failure has occured over the past few years, often credited to be the result of climate change. But abandoning fumigation can result in a loss of frost deflection. Organisations working on climate change adaptation, having only the best in mind especially when it is 'scientifically' proven that it really 'works', are calling for the preservation or revival of traditional practices and have produced statements like 'those traditions must not be allowed to be lost', or 'studies and everything that is done, let's say, more academically, recognises that this knowledge which is ancestral is valid.'
However, deciding which kind of traditional knowledge is to be collected and used as 'data' is a valorised decision made in places other than the local community. This means that it has to fit the wider, in this case scientific knowledge, a system shaped by and, thus, the result of former sociopolitical struggles and negotiations.

As mentioned above, one should question why certain knowledge becomes assured knowledge, and whom this serves. Here we argue that information used at policy levels is passed on from international discussions or processes. When looking at the regional adaptation strategy of Cusco or Chumbivilcas, it becomes obvious that the same language and concepts are used as on national and global levels, inter alia following a linear time concept of task implementation with problem solving goals. One interviewee critically reflected that concepts are usually adopted but working towards developing localized concepts hardly ever takes place.

Where it becomes difficult to match different knowledge systems and to communicate information in a way that people in situ can interpret and use is illustrated by the following quotations of a former local government member: 


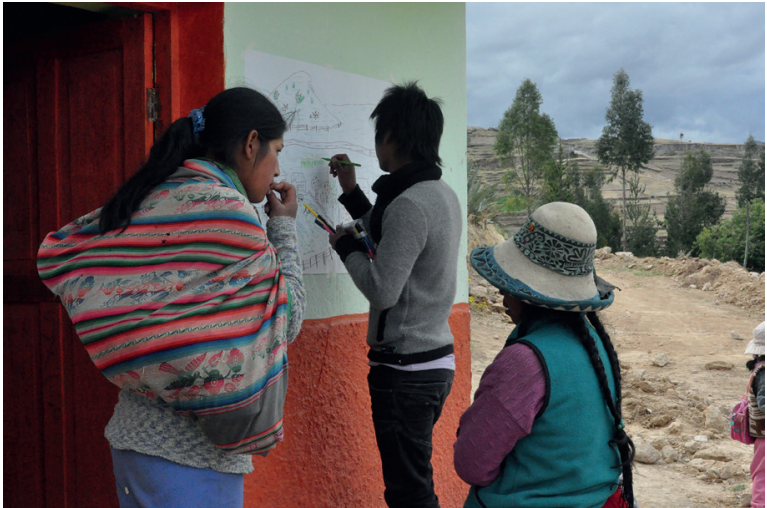

Photo 2: Local workshop in Chacaraya, District Llusco, Department Cusco, Peru (Photo: A. Weber, 14.10.2013)

'The Municipal Environmental Commission was formed. This year it was not possible to implement the other instruments such as the environmental diagnostic, of which a draft has been left, then the environmental agenda has not been achieved to implement, then the organisations did not understand what the Municipal Environmental Commission was and what it served for.'

In this regard, WYNNE (2001) proposes that the gap between science and public knowledge exists because they are both driven by different sets of approaches. While scientists look at 'factual, objective and real' knowledge (Wynne 2001, 445), the public is more interested and driven by emotions based on their daily routines and life problems. RAYGORODETSKY (2011) points out that what 'climate scientists' contribute to the debate should be locally meaningful'. Thus, questions should focus more on what the public needs to know and how individuals will probably interpret the knowledge. Taking local structures into account and communicating in a 'constant translation back and forth across relatively well-articulated global and local knowledge-power formations' (LONG MarTELlO and JASANOFF 2004, 5) is one of the prerequisites of well-functioning and more balanced global climate governance.

\subsection{The role of discourse entanglements}

Successful implementation of actions needs local participation and a population that has faith in the idea, a highly political process (WeISSER et al. 2014). The consideration of discourse entanglements is fundamental when communicating climate change knowledge. In the context of the Peruvian Andes, the long-lasting discourse of 'rural' versus 'urban' and 'tradition/indigenous' versus 'modern' needs to be considered, while also taking the statement of Long MARTELlo and JasanofF (2004) into account, of a 'local not generally recognized knowledge' versus a 'scientific real valid knowledge'. These dichotomies have their roots in colonial times and have been profoundly discussed in Latin American literature, dealing with interculturality, ethnicity, the question of identities and prevailing inequalities, racism, and discrimination (for the Peruvian Andes c.f. De la Cadena 1998, 2000; García 2008; Howard 2007; Poole 1997; Valdivia Corrales 2013). Being aware of this particular Peruvian discourse helps understand the ways that the climate change discourse is perceived, accepted or disapproved. The fact that those who communicate climate change knowledge are mainly 'educated' persons from the cities has widespread implications, as can be seen in the following citation from a Chumbivilcano who studied in Arequipa and came back to his home community:

'For example we engineers are leaving to the communities to teach how to grow potatoes or any other product [...]. Here are the major clashes with the people in rural areas. [...] They just listen to you [but] in the background they say that what [the engineers] are saying has nothing to do with what [the community members] know. [...] The wisdom of the 'original' people is not recognised as such. It is an empirical knowledge and may therefore serve for something, but they are not the decision makers.'

Furthermore he adds:

'All local knowledge is devalued, it is not recognized as such. However, we know that such knowledge in other spaces is valid. We must understand it more from a logic of a dependency of thought.'

A NGO member refered to how this affects their project implementation:

'They started with this project, two or three agronomists, engineers. First they hired a biologist, the biologist came, made a tour in the area, did not like the area and renunced immediately in less than one month. Then the other team made its baseline, identified communities, all alike. There was no, let's say, horizontal relationship we seek between the population and the institution.'

Moreover, the interviewees reflected on how the behaviour of former co-workers coming from the cities to work in rural areas causes problems:

'So you cannot go to the community and say I'm the engineer and you have to respect me.' 
These few citations show how climate change discourse and knowledge communication are embedded in an existing important national discourse. Intented or not, the discourse enters socio-political and thus power structures. But in spite of the outlined disorderly communication, climate change is heard everywhere, showing that the information is somehow appropriated and not completely rejected: 'And yes, there is progress because when you are going to communities they already talk to you of climate change and all that', one NGO-member expressed. And a 22-old student from Quiñota stated:

'Everybody knows about climate change. Hence, if the people are, for example, on their fields and harvest maize and harvest only a little, they say, they have no maize because of climate change.

Today everything is climate change.'

With regard to knowledge communication, prevailing social discourses are of high importance. In the case of the Peruvian Andes the discourse is, on the one hand, particularly accepted because it comes from 'knowing cities', from those who studied, which means from the 'owner' of knowledge; science. This means for the rural population that once again 'the others' are the ones who know and they themselves are, as usual, the 'unknowing'. Consequently, the climate change discourse deepens the already existing inequalities and power constellations. Besides, acceptance does not necessarily mean that this information is of use for the population in situ. On the other hand, the discourse appropriated by the population, as seen in the last citations, is used to explain crop-failures, sicknesses, or plagues. Thus, the international climate change regime should be aware of how climate information is perceived and appropriated, as in the end climate change knowledge could end up in not just supporting adaptation but also as a means of ignoring the multiple reasons for existing problems in different places worldwide. Rather, what should be questioned is whether the aim of the communicated knowledge is really 'achieved'.

\section{Conclusion}

Not only physical climate change is real and everywhere, but the global climate change discourse alone is powerful, influencing societies and places all over the world. While its influential power must not be underestimated, specific socio-cultural particularities should be taken into consideration since the dominating global climate change discourse is individually and culturally specific interpreted and embedded into existing local knowledge. As shown in this paper, a clash exists between scientific knowledge and local knowledge, not only concerning the transmitted information and content but also between the involved actors. Experts often see their knowledge and role superior and locals more often than not do or have to accept this superiority against their own experiences.

The international climate change discourse is embedded in other discourses, existent assumptions and global structures. Whereas the aim to resolve a global problem needs close cooperation between actors on all levels and different socio-cultural and knowledge systems - which is a complex and balancing task - the international cooperation runs the risk of sustaining or even reinforcing inequalities and excluding those who are considered to be the most vulnerable. We see a need to recognise and accept non-Western views and local knowledge systems, local communities' different experiences and understandings of climate change equally alongside the currently dominant one(s) that are derived from negotiation processes at national or even international levels. The broadening of the climate change discourse across various scales is necessary to better understand the problems and aims in the peripheries of the Global South and to heighten the effectiveness of locally adjusted adaptation strategies and measures in spite of the 'real' physical threats of climate change. So, a 'downscaling of climate change adaptation' from international to national and local scales (GERLAK and Schmeier 2014, 377) is needed. 'Discourse and practice is beginning to change but until national and local actors can assert their voices in policy discussions and, more importantly, in decision-making processes, system-wide transformation is unlikely' (World Disasters Report 2015, 117).

Development cooperation is an important transmitter of climate change information and thus of the discourse, in particular for communities in the peripheries of the Global South. This underlines the responsibility of development cooperation to successfully coordinate development and climate change adaptation measures. Furthermore, the transmitters or mediators communicating and translating knowledge back and forward not only need to speak the various languages, but also certainly need to understand both 'cultures' - the one in situ and the science based. Thus, it is necessary to consider national, regional or local discourses, subsiting power structures and prevailing worldviews in which perceptions of time, climate, and environment are embedded. 
More research is needed to evaluate how the most threatened and vulnerable populations perceive and understand climate change and its related consequences, which will help to assess the role of specific actors, assumed risks and potentials for conflicts. We fully agree with the statement by OFFEN $(2014,485)$ that 'the meaning of climate or climate change is not, or should not, be the exclusive purview of science and its practitioners.'

\section{References}

Adger, N.; Aggarwal, P.; Agrawala, S.; Alcamo, J.; Allali, A.; Anisimov, O. et al. (2007): IPCC, 2007: Summary for Policymakers. In: Parry, M.L.; Canziani, O.F.; Palutikof, J.P.; van der Linden, P.J. and Hanson, C.E. (eds.): Climate Change 2007: impacts, adaptation and vulnerability. Contribution of Working Group II to the Fourth Assessment Report of the Intergovernmental Panel on Climate Change. Cambridge, 7-22.

Agrawal, A. (2010): Local institutions and adaptation to climate change. In: Mearns, R. and Norton, A. (eds.): Social dimensions of climate change - equity and vulnerability in a warming world. The World Bank. Washington, D.C., 173-197.

Arnall, A. and Kothari, U. (2015): Challenging climate change and migration discourse: different understandings of timescale and temporality in the Maldives. In: Global Environmental Change 31, 199-206. https:// doi.org/10.1016/j.gloenvcha.2015.01.011

Bawden, G. (1996): The Moche. Cambridge.

BOAS, I. (2014): Where is the South in security discourse on climate change? An analysis of India. In: Critical Studies on Security 2 (2), 148-161. https://doi.org/10.1080/21 624887.2014 .905295

Bose, P.S. (2016): Vulnerabilities and displacements: adaptation and mitigation to climate change as a new development mantra. In: Area 48 (2), 168-175. https://doi. org/10.1111/area.12178

Brace, C. and Geoghegan, H. (2010): Human geographies of climate change: landscape, temporality, and lay knowledges. In: Progress in Human Geography 35 (3), 284-302.

Cannon, T. and Müller-Mahn, D. (2010): Vulnerability, resilience and development discourses in context of climate change. In: Natural Hazards 55 (3), 621-635. https://doi.org/10.1007/s11069-010-9499-4

CAREY, M. (ed.) (2010): In the shadow of melting glaciers. Climate change and Andean society. New York.

Crate, S.A. (2011): Climate and culture: anthropology in the era of contemporary climate change. In: Annual Review of Anthropology 40 (1), 175-194. https://doi. org/10.1146/annurev.anthro.012809.104925
De la Cadena, M. (1998): Silent racism and intellectual superiority in Peru. In: Bulletin of Latin American Research 17 (2), 143-164. https://doi. org/10.1111/j.1470-9856.1998.tb00169.x

De la Cadena, M. (2000): Indigenous Mestizos: the politics of race and culture in Cuzco, Peru, 1919-1991. Durham.

Diemberger, H.; Hastrup, K.; Schaffer, S.; Kennel, C. F.; Sneath, D.; Bravo, M.; Graf, H.-F.; Hobbs, J.; Davis, J.; Nodari, M. L.; Vassena, G.; Irvine, R.; Evans, C.; Strathern, M.; Hulme, M.; Kaser, G. and BodenHORN, B. (2012): Communicating climate knowledge. In: Current Anthropology 53 (2), 226-244. https://doi. org/10.1086/665033

DieTz, K. (2006): Vulnerabilität und Anpassung gegenüber Klimawandel aus sozial-ökologischer Perspektive. Aktuelle Tendenzen und Herausforderungen in der internationalen Klima- und Entwicklungspolitik. Discussion Paper (01/06). Berlin.

Escobar, A. (1995): Encountering development: The making and unmaking of the Third World. Princeton.

ETKIN, D. and Ho, E. (2007): Climate change: perceptions and discourses of risk. In: Journal of Risk Research 10 (5), 623-641. https://doi.org/10.1080/13669870701281462

Foucault, M. (1988): Archäologie des Wissens. Frankfurt/M.

GARcía, M.E. (2008): Desafíos de la interculturalidad. Educación, desarrollo e identidades indígenas en el Perú. Lima.

Gerlak, A.K. and Schmeier, S. (2014): Climate change and transboundary waters: a study of discourse in the Mekong River Commission. In: Journal of Environment \& Development 23 (3), 358-386. https://doi. org/10.1177/1070496514537276

Grube, N. (ed.) (2000): Maya - Gottkönige im Regenwald. Köln.

GTZ (Deutsche Gesellschaft für Technische Zusammenarbeit) (2008): Tackling climate change. Contributions of Capacity Development. Eschborn.

Hannigan, J.A. (1995): Environmental sociology: a social constructionist perspective. London.

Hanson-Easey, S.; Williams, S.; Hansen, A.; Fogarty, K. and BI, P. (2015): Speaking of climate change: a discursive analysis of lay understandings. In: Science Communication 37 (2), 217-239. https://doi.org/ $10.1177 / 1075547014568418$

Hastrup, K. (2013): Anthropological contributions to the study of climate: past, present, future. In: WIREs Climate Change 4, 269-281. https://doi.org/10.1002/ wcc. 219

Howard, R. (2007): Por los Linderos de la Lengua. Ideologías lingüísticas en los Andes. Lima.

Hulme, M. and Mahony, M. (2010): Climate Change: what do we know about the IPCC? In: Progress in Physical Geography 34 (5), 705-718. https://doi.org/ $10.1177 / 0309133310373719$ 
IPCC (2001): Climate Change 2001: Synthesis Report. A Contribution of Working Groups I, II, and III to the Third Assessment Report of the Intergovernmental Panel on Climate Change. Cambridge, New York.

- (2007): Climate Change 2007: Synthesis Report. Contribution of Working Groups I, II and III to the Fourth Assessment Report of the Intergovernmental Panel on Climate Change. Geneva.

- (2013): Climate Change 2013: The Physical Science Basis. Contribution of Working Group I to the Fifth Assessment Report of the Intergovernmental Panel on Climate Change. Cambridge and New York.

Isaksen, K.-A. and Stokke, K. (2014): Changing climate discourse and politics in India. Climate Change as challenge and opportunity for diplomacy and development. In: Geoforum 57, 110-119. https://doi.org/10.1016/j. geoforum.2014.08.019

Jung, M. (2006): Diskurshistorische Analyse. Eine Linguistische Perspektive. In: Keller, R.; Hirseland, A.; SchneIDER, W. and VIEHÖVER, W. (eds.): Handbuch sozialwissenschaftliche Diskursanalyse. Band 1: Theorien und Methoden. Wiesbaden, 31-54.

Keller, R.; Hirseland, A.; Schneider, W. and Viehöver, W. (2006): Zur Aktualität sozialwissenschaftlicher Diskursanalyse - Eine Einführung. In: Keller, R.; Hirseland, A.; Schneider, W. and Viehöver, W. (eds.): Handbuch sozialwissenschaftliche Diskursanalyse. Band 1: Theorien und Methoden. Wiesbaden, 7-30.

Kronik, J. and Verner, D. (2010): The role of indigenous knowledge in crafting adaptation and mitigation strategies for climate change in Latin America. In: MEARns, R. and Norton, A. (eds.): Social Dimensions of Climate Change - Equity and Vulnerability in a Warming World. Washington, D.C., 145-169.

Lo, A.Y. (2016): Public discourses of climate change in Hong Kong. In: Journal of Environmental Policy \& Planning 18 (1), 27-46. https://doi.org/10.1080/1523 908X.2015.1040545

Long Martello, M. and Jasanoff, S. (2004): Introduction. Globalization and environmental governance. In: Long Martello, M. and Jasanoff, S. (eds.): Earthly politics - local and global in environmental governance. Cambridge, 1-29. https://doi.org/10.1016/b978190399665-2/50020-2

NADASDY, P. (1999): The politics of TEK: power and the "integration" of knowledge. In: Arctic Anthropology 36 (1-2): 1-18. http:/ / www.jstor.org/stable/40316502

OfFEN, K. (2014): Historical geography III: climate matters. In: Progress in Human Geography 38 (3), 476-489. https://doi.org/10.1177/0309132513501429

Pasgaard, M.; Dalsgaard, B.; Maruyama, P.K.; Sandel, B. and Strange, N. (2015): Geographical imbalances and divides in the scientific production of climate change knowledge. In: Global Environmental Change 35, 279_ 288. https://doi.org/10.1016/j.gloenvcha.2015.09.018

Poole, D. (1997): Vision, race, and modernity: a visual economy of the Andean image world. Princeton.

Popke, J.; Curtis, S. and Gamble, D.W. (2016): A social justice framing of climate change discourse and policy: adaptation, resilience and vulnerability in a Jamaican agricultural landscape. In: Geoforum 73, 70-80. https:// doi.org/10.1016/j.geoforum.2014.11.003

RAYGORODETSKY, G. (2011): Why traditional knowledge holds the key to climate change. http://unu.edu/publications/articles/why-traditional-knowledge-holds-thekey-to-climate-change.html. Accessed 01 December 2016

Román, M.; Linnér, B. and Mickiwitz, P. (2012): Development policies as a vehicle for addressing climate change. In: Climate and Development 4 (3), 251-260. https:// doi.org/10.1080/17565529.2012.698590

SCHIPPER, L. (2007): Climate change adaptation and development: exploring the linkages. Tyndall Working Paper 107.

TARNOCZI, T. (2011): Transformative learning and adaptation to climate change in the Canadian Prairie agro-ecosystem. In: Change 16, 387-406. https:/ / doi.org/10.1007/ s11027-010-9265-7

UNDP (United Nations Development Programme) (2008): Human Development Report 2007/2008. Fighting climate change: human solidarity in a divided World. New York.

Valdivia Corrales, G. (2013): El neoliberlismo y las sociedades pastoriles del sur andino - un caso de extrema exclusión y pobreza en los Andes Peruanos. In: Gentili, P. (ed.): La Construcción Social de La Pobreza En América Latina Y El Caribe. Buenos Aires, 283-316.

VIehöVer, W. (2011): Die Politisierung des globalen Klimawandels und die Konstitution des transnationalen Klimaregimes. In: Gross, M. (ed.): Handbuch Umweltsoziologie. Wiesbaden, 671-691. https://doi. org/10.1007/978-3-531-93097-8_33

- (2012): Öffentliche Erzählungen und der globale Wandel des Klimas. In: Arnold, M.; Dressel, G. and Viehöver, W. (eds.): Erzählungen im Öffentlichen. Wiesbaden, 173215. https://doi.org/10.1007/978-3-531-93256-9_6

Von Storch, H. and Stehr, N. (1997): The case for the social sciences in climate research. In: Ambio 26 (1), $66-71$.

Voss, M. (ed.) (2010): Der Klimawandel - Sozialwissenschaftliche Perspektiven. Wiesbaden.

Watson, A. and Huntington, O. (2014): Transgressions of the man on the moon: climate change, indigenous expertise, and the posthumanist ethics of place and space. In: GeoJournal 79, 721-736. https://doi.org/10.1007/ s10708-014-9547-9 
WeART, S. (2011): The development of the concept of dangerous anthropogenic climate change. In: DRYzek, J.S.; Norganrd, R.B. and Schlosberg, D. (eds.): Oxford handbook of climate change and society. Oxford, 67-81. https://doi.org/10.1093/oxford$\mathrm{hb} / 9780199566600.003 .0005$

WeEdon, C. (1987): Feminist practice and post-structuralist theory. Oxford.

Weingart, P.; Engels, A. and Pansegrau, P. (2008): Von der Hypothese zur Katastrophe: Der anthropogene Klimawandel im Diskurs zwischen Wissenschaft, Politik und Massenmedien. Opladen.

Weisser, F.; Bollig, M.; Doevenspeck, M. and MüllerMahn, D. (2014): Translating the 'adaptation to climate change' paradigm: the politics of a travelling idea in Africa. In: The Geographical Journal 180 (2), 111-119. https://doi.org/10.1111/geoj.12037

Williams, C.; Galloway McLean, K.; Raygorodetsky, G.; Ramos-Castillo, A. and Barrett, B. (2012): Traditional knowledge and climate science. Tokyo.

World BANK (2010): Development and climate change. World development report 2010. Washington, D.C.

- (2012): Turn down the heat: climate extremes, regional impacts, and the case for resilience. Washington, D.C.

World Disasters Report (2015): Focus on local actors, the key to humanitarian effectiveness. Ed. by International Federation of Red Cross and Red Crescent Societies. Geneva.

Wynne, B. (2001): Creating public alienation: Expert cultures of risk and ethics on GMOs. In: Science as Culture 10, 445-481.https://doi.org/10.1080/09505430120093586

\section{Authors}

Anja Weber, M.A. Prof. Dr. Matthias Schmidt Institute of Geography University of Augsburg Alter Postweg 118 86159 Augsburg Germany anjaweber00@hotmail.com schmidt@geo.uni-augsburg.de 